\title{
In vitro study on the schedule-dependency of the interaction between pemetrexed, gemcitabine and irradiation in non-small cell lung cancer and head and neck cancer cells
}

An Wouters ${ }^{1 *}$, Bea Pauwels ${ }^{1}$, Filip Lardon ${ }^{1}$, Greet GO Pattyn ${ }^{1}$, Hilde AJ Lambrechts', Marc Baay ${ }^{1}$, Paul Meijnders ${ }^{2}$, Jan B Vermorken ${ }^{1}$

\begin{abstract}
Background: Based on their different mechanisms of action, non-overlapping side effects and radiosensitising potential, combining the antimetabolites pemetrexed (multitargeted antifolate, MTA) and gemcitabine (2',2'difluorodeoxycytidine, dFdC) with irradiation (RT) seems promising. This in vitro study, for the first time, presents the triple combination of MTA, dFdC and irradiation using various treatment schedules.

Methods: The cytotoxicity, radiosensitising potential and cell cycle effect of MTA were investigated in A549 (NSCLC) and CAL-27 (SCCHN) cells. Using simultaneous or sequential exposure schedules, the cytotoxicity and radiosensitising effect of $24 \mathrm{~h}$ MTA combined with $1 \mathrm{~h}$ or $24 \mathrm{~h} \mathrm{dFdC}$ were analysed.
\end{abstract}

Results: Including a time interval between MTA exposure and irradiation seemed favourable to MTA immediately preceding or following radiotherapy. MTA induced a significant $S$ phase accumulation that persisted for more than $8 \mathrm{~h}$ after drug removal. Among different MTA/dFdC combinations tested, the highest synergistic interaction was produced by $24 \mathrm{~h}$ MTA followed by $1 \mathrm{~h} \mathrm{dFdC}$. Combined with irradiation, this schedule showed a clear radiosensitising effect.

Conclusions: Results from our in vitro model suggest that the sequence $24 \mathrm{~h} \mathrm{MTA} \rightarrow 1 \mathrm{~h} \mathrm{dFdC} \rightarrow \mathrm{RT}$ is the most rational design and would, after confirmation in an in vivo setting, possibly provide the greatest benefit in the clinic.

\section{Background}

During the past decades, the use of chemotherapeutic drugs in combination with radiotherapy has become a common strategy for the treatment of different solid tumours, improving cancer care dramatically. Combining chemotherapy and radiotherapy has a solid and appealing biologic rationale. Firstly, whereas radiotherapy is aimed at controlling the primary tumour, the cytotoxic drug also eradicates distant micrometastases, a scenario defined as spatial cooperation. Secondly,

\footnotetext{
* Correspondence: an.wouters@ua.ac.be

'Laboratory of Cancer Research and Clinical Oncology, Department of Medical Oncology, University of Antwerp, Universiteitsplein 1, 2610 Wilrijk, Belgium

Full list of author information is available at the end of the article
}

chemotherapy can possibly enhance the effects of ionising radiation, a process called radiosensitisation [1].

The availability of several new active compounds has led to the development of promising new combinations. Many of those chemoradiotherapy combinations include antimetabolites, because of their efficacy, their generally well-defined mechanisms of action and mostly manageable toxicities [2]. In this in vitro study, we describe for the first time the triple combination of the antimetabolites gemcitabine and pemetrexed with irradiation in two human tumour cell lines.

Gemcitabine $\left(2^{\prime}, 2^{\prime}\right.$-difluorodeoxycytidine, $\left.\mathrm{dFdC}\right)$ is a synthetic pyrimidine nucleoside analogue clinically active against a wide variety of solid tumours. Transport of gemcitabine across the plasma membrane is mostly 
mediated by the human equilibrative nucleoside transporter 1 (hENT1) [3]. Intracellularly, the prodrug gemcitabine requires phosphorylation and hence activation by deoxycytidine kinase (dCK). The diphosphate (dFdCDP) and triphosphate (dFdCTP) forms of the drug are presumed to be responsible for the cytotoxic effect, as they inhibit ribonucleotide reductase or are incorporated into the DNA, leading to chain termination, respectively [4].

In addition to its cytotoxic effect, gemcitabine has potent radiosensitising properties, as shown in both preclinical and clinical settings [5]. The current evidence suggests that accumulation in the $\mathrm{S}$ phase of the cell cycle, depletion of dATP pools, reduction of apoptotic threshold, inhibition of DNA synthesis and reduction of DNA repair might contribute to, or might even be essential for gemcitabine-mediated radiosensitisation [6-10]. Recently, Pauwels et al could grant a role for cell cycle perturbations and activation of the extrinsic apoptotic pathway in the radiosensitising effect of gemcitabine [10]. On the other hand, it has been suggested that radiosensitisation by gemcitabine may be primarily explained by the significant inhibition of DNA repair following combined radiation and gemcitabine treatment. DNA repair pathways using short DNA patches, such as non-homologous end joining and base excision repair, are thought not to play an important role in gemcitabine-mediated radiosensitisation $[9,11]$. Instead, homologous recombination, a long-patch DNA repair pathway, has been argued to be the target for gemcitabine to enhance cellular radiosensitivity [9]. Moreover, the role of the mismatch repair (MMR) system, an intermediate-patch DNA repair pathway, may be of relevance [12]. A dramatic increase of nucleotide misincorporations in gemcitabine-treated (MMR deficient) cells was demonstrated, presumably due to dNTP pool imbalances (particularly dATP depletion) $[8,13]$. Van Bree et al showed that MMR proficiency reduced radiosensitisation after $24 \mathrm{~h}$ incubation with a low dose of gemcitabine, suggesting that the MMR status might affect the recovery from gemcitabine treatment [14].

Pemetrexed (multitargeted antifolate, MTA) is a newgeneration antimetabolite with antitumour activity against a broad range of human malignancies [15]. It was approved by the FDA for first-line treatment of inoperable malignant mesothelioma in combination with cisplatin [16]. Successively, pemetrexed was also investigated in non-small cell lung cancer (NSCLC), where it was FDA-approved as second-line therapy in patients with previously chemotherapy-treated advanced NSCLC [17], as first-line therapy, in combination with cisplatin, for chemotherapy-naive NSCLC patients [18], and, very recently, for maintenance treatment of patients with locally advanced or metastatic non-squamous NSCLC whose disease had not progressed after four cycles of platinum-based first-line chemotherapy [19].

Pemetrexed acts as a multitargeted antifolate by inhibiting multiple key enzymes involved in both pyrimidine and purine synthesis, its primary targets being thymidylate synthase (TS), dihydrofolate reductase (DHFR) and glycinamide ribonucleotide formaldehyde transferase (GARFT). Pemetrexed enters the cell mainly by a reduced folate carrier system. Once inside the cell, pemetrexed is an excellent substrate for the enzyme folylpolyglutamate synthase (FPGS) [20], which rapidly converts pemetrexed to its active polyglutamate derivatives that have a substantially higher potency for inhibition of TS and GARFT [21]. It is believed that polyglutamation of pemetrexed plays a profound role in determining both the selectivity and the antitumour activity of this agent.

The ability of pemetrexed to deplete cellular nucleotide pools, to modulate the cell cycle, and to induce apoptosis makes this drug an attractive cytotoxic agent for polychemotherapy regimens and combination with radiotherapy [22]. In preclinical studies, radiosensitisation by pemetrexed was observed in human colon, breast, cervix and lung carcinoma cells [23]. In vivo, combination of pemetrexed with fractionated radiotherapy produced additive to greater than additive antitumour activity in murine and human tumour xenografts $[24,25]$. In a phase I study, it was suggested that pemetrexed could be administered at systemically active doses in combination with radiotherapy [26]. These findings prompted further investigation of the radiosensitising effect of pemetrexed.

The aim of the present study is the exploration of the cytotoxic (and not toxic) effects of combinations of pemetrexed and gemcitabine alone or combined with irradiation using various treatment schedules in two human carcinoma cell lines. Given the three approved indications for pemetrexed in the treatment of NSCLC, we selected the A549 NSCLC cell line. As radiotherapy in combination with gemcitabine is reported to be feasible and highly active in the treatment of locally advanced squamous cell carcinoma of the head and neck (SCCHN) [27], we also included the CAL-27 SCCHN cell line.

\section{Methods \\ Cell lines}

The cell lines used in this study were CAL-27 (squamous cell carcinoma of the tongue) and A549 (lung adenocarcinoma). A549 was cultured in RPMI-1640 medium, supplemented with $10 \%$ dialysed foetal calf serum, $2 \mathrm{mM}$ glutamine and $1 \mathrm{mM}$ sodium pyruvate. CAL-27 was cultured in DMEM medium, supplemented 
with $10 \%$ dialysed foetal calf serum and $2 \mathrm{mM}$ glutamine (Invitrogen, Merelbeke, Belgium). No antibiotics were used. Cells were grown as monolayers and cultures were maintained in exponential growth in a humidified $5 \% \mathrm{CO}_{2} / 95 \%$ air atmosphere at $37^{\circ} \mathrm{C}$. For subsequent experiments, cells were collected by trypsinisation, counted, and plated as specified below. The cell doubling times of A549 and CAL-27 cells in our experimental conditions were $28 \mathrm{~h}$ and $33 \mathrm{~h}$, respectively.

\section{Cytotoxicity experiments}

Cells were plated in 48 well plates and seeding densities were 500 cells $/ \mathrm{cm}^{2}$ for A549 and 1400 cells $/ \mathrm{cm}^{2}$ for CAL-27, assuring exponential growth. Cells were incubated with pemetrexed alone (0-2000 nM for 24 h), gemcitabine alone $(0-100 \mathrm{nM}$ for $24 \mathrm{~h}$ or $0-5 \mu \mathrm{M}$ for $1 \mathrm{~h}$ ) or with a combination of both, where one drug was used at a fixed concentration, while a concentration range of the other drug was added. Three combination schedules were tested: (1) simultaneous exposure to pemetrexed and gemcitabine for $24 \mathrm{~h}$; (2) gemcitabine for $1 \mathrm{~h}$ or $24 \mathrm{~h}$ immediately followed by pemetrexed for $24 \mathrm{~h}$; (3) pemetrexed for $24 \mathrm{~h}$ immediately followed by gemcitabine for $1 \mathrm{~h}$ or $24 \mathrm{~h}$. Cell survival was determined by the sulforhodamine B (SRB) assay, as previously described [28]. The experimental conditions adopted in this study, including time of exposure to gemcitabine and pemetrexed, are similar to those selected in previous studies $[10,22,29,30]$. In simultaneous experiments, treatment exposure time was $24 \mathrm{~h}$. To reduce the variation in drug efficacy associated with time of drug addition relative to plating time, the sequential schemes examined the effect of both a 1-h and a 24-h gemcitabine exposure on the cytotoxicity of pemetrexed. Since several clinical studies have indicated that administration of gemcitabine and pemetrexed immediately after each other is well tolerated and clinically active [31-33], no wash out with drug-free medium was included in the sequential treatment schedules.

\section{Chemoradiation experiments}

Cells were plated in 48 well plates, with plating densities assuring exponential growth during the experiments. The radiosensitising effect of pemetrexed alone was investigated by including different time intervals $(24 \mathrm{~h}$, $8 \mathrm{~h}, 4 \mathrm{~h}, 1 \mathrm{~h}, 0 \mathrm{~h}$ ) between $24 \mathrm{~h}$ pemetrexed treatment and irradiation (0-8 Gy, room temperature, linear accelerator (URA, Antwerp)). The same time intervals as in a previous study investigating the schedule-dependency of gemcitabine treatment combined with radiation were included [34]. In additional experiments, cells were first irradiated, immediately followed by $24 \mathrm{~h}$ incubation with pemetrexed. The triple interaction between pemetrexed, gemcitabine and irradiation was investigated including the three combination schedules previously mentioned, immediately followed by irradiation.

After 7 or 8 days, survival was determined by the SRB assay. For in vitro radiosensitivity testing, this method was comparable to the clonogenic assay, taking into account some critical aspects [28].

\section{Cell cycle experiments}

Cells were plated in 6-well plates and incubated with $50 \mathrm{nM}$ (CAL-27) or $100 \mathrm{nM}$ (A549) pemetrexed for 24 h. Cell cycle analysis was performed $0,1,4,8$ or $24 \mathrm{~h}$ after drug wash out (referred to as $24+0,24+1,24+4$, $24+8$ and $24+24$ respectively). Hence, cells were treated with pemetrexed using the same treatment schedules as adopted in the pemetrexed-radiotherapy experiments, but without subsequent radiation. As such, cell cycle perturbations at the time of irradiation were measured. Cell cycle distribution was monitored according to the Vindelov method, as described previously [34]. Samples were analysed using a FACScan flow cytometer (Becton Dickinson). Histograms of DNA content were analysed using FlowJo software to determine the fractions in each phase of the cell cycle $\left(G_{0} / G_{1}, S\right.$ and $\left.G_{2} / M\right)$. The Watson-Pragmatic model was used to fit curves to the stages of the cell cycle [35].

\section{Statistical analysis}

All experiments were performed at least three times. The results are presented as mean \pm SD. Possible significant differences $(\mathrm{p}<0.05)$ were evaluated with two-sample t-tests and two-way ANOVA, using SPSS v16.0 software.

Survival rates were calculated by: [mean optical density (OD) of treated cells/mean OD of control cells] $\times$ $100 \%$. Radiation dose-survival curves were fitted according to the linear-quadratic model using WinNonlin software (Pharsight, Mountain View, USA) with survival = $\exp \left(-\alpha D-\beta D^{2}\right)$. The radiation dose-survival curves were corrected for the cytotoxic effect of the drugs alone. The following parameters were calculated: $\mathrm{IC}_{50}$ (drug concentration causing $50 \%$ growth inhibition); ID $_{50}$ (radiation dose causing 50\% growth inhibition); $\mathrm{SF}_{2}$ (surviving fraction at $2 \mathrm{~Gy}$ ); and MID (mean inactivation dose, calculated by numeric integration of the linearquadratic curve [36]). The radiosensitising effect was represented by the dose enhancement factor (DEF), calculated as the $\mathrm{ID}_{50}$ for control, untreated cells divided by the $\mathrm{ID}_{50}$ for the treated cells.

The interaction between pemetrexed, gemcitabine and/or radiation was analysed using CalcuSyn software (Biosoft, Cambridge, UK) to determine possible synergism. Data from the cell survival curves were expressed as the fraction of cells killed by the individual drugs or the combination in drug-treated cells compared with 
untreated cells. The CalcuSyn program is based upon the Chou-Talalay method, which calculates the combination index $(\mathrm{CI})$. The analysis is performed based on the following equation: $\mathrm{CI}=(\mathrm{D})_{1} /\left(\mathrm{D}_{\mathrm{x}}\right)_{1}+(\mathrm{D})_{2} /\left(\mathrm{D}_{\mathrm{x}}\right)_{2}$ where $(D)_{1}$ and $(D)_{2}$ are the doses (or concentrations) of drug 1 and drug 2 that have $\mathrm{x} \%$ effect when used in combination and $\left(D_{x}\right)_{1}$ and $\left(D_{x}\right)_{2}$ are the doses of drug 1 and drug 2 that have the same $\mathrm{x} \%$ effect (i.e. isoeffect) when used alone. $\left(D_{x}\right)_{1}$ and $\left(D_{x}\right)_{2}$ can be readily calculated from the median-effect equation of Chou: $D_{x}=$ $D_{m}\left[f_{a} /\left(1-f_{a}\right)\right]^{1 / m}$, where $f_{a}$ is the fraction affected, $D_{m}$ is the median-effect dose $\left(\mathrm{IC}_{50}\right.$ or $\left.\mathrm{ID}_{50}\right)$ that inhibits the system under study by $50 \%$ and $\mathrm{m}$ is the coefficient signifying the sigmoidicity of the dose-effect relationship [37]. The CI values obtained from the classic (mutually exclusive) isobologram calculations were used. $\mathrm{CI}<1.0$, $\mathrm{CI}=1.0$ and $\mathrm{CI}>1.0$ indicate synergism, additivity or antagonism, respectively. Moderate synergism is depicted by $\mathrm{CI}$ values between 0.7 and 0.9 , synergism by CI values below 0.7 .

\section{Results}

\section{Cytotoxicity of pemetrexed alone}

A clear concentration-dependent cytotoxic effect of pemetrexed was observed in CAL-27 and A549 cells, with $\mathrm{IC}_{50}$ values of $118.77 \pm 17.28 \mathrm{nM}$ and $629.89 \pm$ $68.77 \mathrm{nM}$ respectively. The cytotoxicity of pemetrexed was greatly dependent on the cell line used, as for example in the PANC-1 pancreatic cell line, no doseresponse relationship was observed and concentrations up to $1500 \mu \mathrm{M}$ induced only $30 \%$ cell kill.

\section{Combining pemetrexed with radiation}

To investigate potential interactions between pemetrexed and radiation therapy, CAL-27 and A549 tumour cells were exposed to various doses of pemetrexed for $24 \mathrm{~h}$ (0-100 nM for CAL-27; 0-500 nM for A549), immediately followed by irradiation (0-8 Gy) (table 1$)$. No concentration-dependent radiosensitising effect of MTA was observed in CAL-27 cells, with DEF values around 1.00 for all concentrations tested. CI analysis showed that $24 \mathrm{~h}$ incubation with MTA immediately before irradiation resulted in moderate antagonism $(1.1<\mathrm{CI}<1.3)$. In the A549 cell line, DEFs slightly decreased with an increasing concentration of MTA. The mean CI varied from $0.689 \pm 0.079$ to $0.887 \pm$ 0.294 , indicating synergism to additivity.

Irradiation preceding $24 \mathrm{~h}$ incubation with MTA resulted in an additive effect in CAL-27 cells, with DEFs ranging from $0.87 \pm 0.06$ to $1.00 \pm 0.24$ and mean CI values of $1.005 \pm 0.080$ to $1.039 \pm 0.098$. In A549 cells, DEFs indicated a slightly radioprotective effect for this treatment schedule $(0.7<\mathrm{DEF}<0.9)$. A closer look at the $\mathrm{CI}$ analysis (figure $1 \mathrm{~A}$ ) showed that the interaction was synergistic to moderately synergistic in the lower dose range and shifted towards antagonism with increasing doses of irradiation. This is also reflected in the dosesurvival curves.

To examine the role of a time interval between pemetrexed and radiation treatment, CAL-27 and A549 cells were incubated with only slightly cytotoxic concentrations of MTA (i.e. $50 \mathrm{nM}$ and $100 \mathrm{nM}$ for resp. CAL-27 and A549) (figure 1B, C). Statistical analysis by two-way ANOVA showed that the DEF was significantly influenced by the time interval between MTA treatment and irradiation in both CAL-27 $(\mathrm{p}=0.005)$ and A549 ( $\mathrm{p}=$ 0.014 ) cells. A $1 \mathrm{~h}$ time interval between $24 \mathrm{~h}$ MTA and irradiation resulted in a clear radiosensitising effect in both cell lines, with DEF $1.52 \pm 0.39$ for A549 cells and $1.46 \pm 0.21$ for CAL-27 cells (which was significantly higher than the DEF for 24 h MTA immediately followed by RT, $\mathrm{p}=0.008$ ). In the CAL-27 cell line, radiosensitisation was also observed after a $24 \mathrm{~h}$ or $8 \mathrm{~h}$ time interval (DEF resp. $1.59 \pm 0.53$ and $1.23 \pm 0.31$ ), with CI analysis indicating moderate synergism at the $8 \mathrm{~h}$ time interval. In A549 cells, CI values increased from $0.677 \pm$ 0.076 for the $1 \mathrm{~h}$ interval (synergism) to $0.832 \pm 0.067$ for the $24 \mathrm{~h}$ interval (moderate synergism). Concomitantly, DEF values gradually decreased with an increasing time interval between incubation with MTA and irradiation.

\section{Cell cycle distribution}

Table 2 summarises the cell cycle distribution of CAL27 and A549 cells after incubation with pemetrexed for $24 \mathrm{~h}$, followed by a drug free period of $0,1,4,8$ or 24 $\mathrm{h}$. Treatment with pemetrexed for $24 \mathrm{~h}$ induced a significant increase in the percentage of $\mathrm{S}$ phase cells (control: $37.1 \pm 1.3 \%$; $24+0: 66.5 \pm 6.2 \%$ in A549 cells), accompanied by a significant decrease in the number of $\mathrm{G}_{0 / 1}$ phase cells (control: $49.5 \pm 3.1 \%$; $24+0: 23.3 \pm 6.1 \%$ in A549 cells). These changes in cell cycle distribution were observed for up to $8 \mathrm{~h}$ after drug removal, whereas drug wash out for $24 \mathrm{~h}$ almost restored the normal distribution (figure 2). Statistical analysis using two-way ANOVA revealed that the number of $S$ phase cells was significantly influenced depending on the cell line (CAL-27 vs. A549), duration of drug wash out and concentration of pemetrexed (control vs. treated). Post hoc analysis revealed a significant difference in the percentage of S phase cells between the $24+24$ schedule versus the $24+1,24+4$ and $24+8$ schedules.

\section{Combining pemetrexed with gemcitabine}

Considering the lack of concordance among previous preclinical studies on pemetrexed-gemcitabine combinations with regard to the preferable sequence of drug administration, we first investigated different 
Table $1 \mathrm{DEF}, \mathrm{Cl}, \mathrm{ID}_{50}, \mathrm{SF}_{2}$ and \% survival (representing the cytotoxic effect of treatment with MTA alone, $0 \mathrm{~Gy}$ ) for irradiation (RT) given alone or in combination with MTA using different treatment schedules: 24 h MTA immediately followed by RT; RT immediately followed by $24 \mathrm{~h}$ MTA; $24 \mathrm{~h}$ MTA followed by different time intervals (24, 8, 4, 1, 0 h) and subsequent irradiation

\begin{tabular}{|c|c|c|c|c|c|c|c|c|c|c|c|c|c|c|c|}
\hline & \multirow[t]{2}{*}{ Condition } & \multicolumn{3}{|c|}{ DEF } & \multicolumn{3}{|c|}{$\mathrm{Cl}$} & \multicolumn{3}{|c|}{$\mathrm{ID}_{50}$} & \multicolumn{3}{|c|}{$\mathrm{SF}_{2}$} & \multicolumn{2}{|c|}{$\%$ survival } \\
\hline & & mean & SD & & mean & SD & & mean & SD & & mean & SD & & mean & SD \\
\hline \multirow[t]{11}{*}{ CAL-27 } & RT & & & & & & & 1.94 & 0.47 & & 48.37 & 9.31 & & $100 \%$ & $0 \%$ \\
\hline & 24 h 50 nM MTA $\rightarrow$ RT & 1.04 & 0.23 & & 1.145 & 0.132 & & 1.97 & 0.45 & & 49.25 & 9.71 & & $97 \%$ & $11 \%$ \\
\hline & $24 \mathrm{~h} 75 \mathrm{nM}$ MTA $\rightarrow$ RT & 1.01 & 0.10 & & 1.260 & 0.270 & & 1.94 & 0.54 & & 47.75 & 7.53 & & $70 \%$ & $12 \%$ \\
\hline & 24 h 100 nM MTA $\rightarrow$ RT & 1.04 & 0.03 & & 1.229 & 0.269 & & 1.86 & 0.27 & & 47.34 & 4.31 & & $57 \%$ & $4 \%$ \\
\hline & $\mathrm{RT} \rightarrow 24$ h 50 nM MTA & 0.87 & 0.06 & & 1.039 & 0.098 & & 1.86 & 0.46 & & 46.21 & 9.19 & & $88 \%$ & $4 \%$ \\
\hline & $\mathrm{RT} \rightarrow 24 \mathrm{~h} 75 \mathrm{nM}$ MTA & 0.94 & 0.14 & & 1.023 & 0.063 & & 1.77 & 0.63 & & 44.56 & 12.48 & & $71 \%$ & $8 \%$ \\
\hline & $\mathrm{RT} \rightarrow 24 \mathrm{~h} 100 \mathrm{nM}$ MTA & 1.00 & 0.24 & & 1.005 & 0.080 & & 1.65 & 0.41 & & 42.40 & 10.00 & & $59 \%$ & $12 \%$ \\
\hline & $24 \mathrm{~h} 50 \mathrm{nM} \mathrm{MTA} \rightarrow 24 \mathrm{~h} \rightarrow \mathrm{RT}$ & 1.59 & 0.53 & $\dagger$ & 0.915 & 0.063 & & 1.71 & 0.66 & & 43.37 & 12.35 & & $70 \%$ & $21 \%$ \\
\hline & $24 \mathrm{~h} 50 \mathrm{nM}$ MTA $\rightarrow 8 \mathrm{~h} \rightarrow \mathrm{RT}$ & 1.23 & 0.31 & & 0.844 & 0.091 & $*$ & 1.55 & 0.58 & & 39.45 & 12.88 & & $88 \%$ & $4 \%$ \\
\hline & $24 \mathrm{~h} 50 \mathrm{nM} \mathrm{MTA} \rightarrow 4 \mathrm{~h} \rightarrow \mathrm{RT}$ & 1.12 & 0.24 & & 0.965 & 0.106 & & 1.68 & 0.58 & & 42.34 & 12.02 & & $90 \%$ & $6 \%$ \\
\hline & $24 \mathrm{~h} 50 \mathrm{nM}$ MTA $\rightarrow 1 \mathrm{~h} \rightarrow \mathrm{RT}$ & 1.46 & 0.21 & $\dagger$ & 0.932 & 0.073 & & 1.21 & 0.35 & $\dagger$ & 32.45 & 8.43 & $\dagger$ & $98 \%$ & $4 \%$ \\
\hline \multirow[t]{12}{*}{ A549 } & RT & & & & & & & 2.41 & 0.39 & & 56.26 & 6.18 & & $100 \%$ & $0 \%$ \\
\hline & $24 \mathrm{~h} 100 \mathrm{nM}$ MTA $\rightarrow$ RT & 1.29 & 0.25 & & 0.698 & 0.079 & $* *$ & 1.77 & 0.36 & & 45.39 & 7.15 & & $87 \%$ & $11 \%$ \\
\hline & $24 \mathrm{~h} 200 \mathrm{nM}$ MTA $\rightarrow$ RT & 1.19 & 0.06 & & 0.855 & 0.197 & $*$ & 2.18 & 0.34 & & 52.16 & 4.46 & & $65 \%$ & $12 \%$ \\
\hline & 24 h 300 nM MTA $\rightarrow$ RT & 0.97 & 0.23 & & 0.887 & 0.294 & * & 2.84 & 1.03 & & 57.46 & 8.70 & & $52 \%$ & $14 \%$ \\
\hline & 24 h 500 nM MTA $\rightarrow$ RT & 0.75 & 0.28 & & 0.793 & 0.288 & $*$ & 3.83 & 1.56 & & 62.76 & 10.23 & & $38 \%$ & $13 \%$ \\
\hline & $\mathrm{RT} \rightarrow 24$ h 200 nM MTA & 0.86 & 0.19 & & 0.996 & 0.124 & & 2.77 & 0.20 & & 60.24 & 3.01 & & $68 \%$ & $19 \%$ \\
\hline & $\mathrm{RT} \rightarrow 24$ h 300 nM MTA & 0.80 & 0.10 & & 0.862 & 0.173 & $*$ & 2.98 & 0.30 & & 61.48 & 2.65 & & $52 \%$ & $16 \%$ \\
\hline & $\mathrm{RT} \rightarrow 24$ h 500 nM MTA & 0.76 & 0.11 & & 0.723 & 0.166 & * & 3.11 & 0.19 & & 62.75 & 1.09 & & $38 \%$ & $15 \%$ \\
\hline & $24 \mathrm{~h} 100 \mathrm{nM}$ MTA $\rightarrow 24 \mathrm{~h} \rightarrow \mathrm{RT}$ & 0.98 & 0.15 & & 0.832 & 0.067 & * & 2.16 & 0.11 & & 52.70 & 2.00 & & $84 \%$ & $16 \%$ \\
\hline & $24 \mathrm{~h} 100 \mathrm{nM}$ MTA $\rightarrow 8 \mathrm{~h} \rightarrow \mathrm{RT}$ & 1.21 & 0.18 & & 0.731 & 0.129 & $*$ & 2.02 & 0.24 & & 50.62 & 4.87 & & $85 \%$ & $9 \%$ \\
\hline & $24 \mathrm{~h} 100 \mathrm{nM}$ MTA $\rightarrow 4 \mathrm{~h} \rightarrow \mathrm{RT}$ & 1.56 & 0.41 & & 0.718 & 0.103 & $*$ & 1.63 & 0.35 & & 42.19 & 6.30 & & $94 \%$ & $10 \%$ \\
\hline & $24 \mathrm{~h} 100 \mathrm{nM}$ MTA $\rightarrow 1 \mathrm{~h} \rightarrow \mathrm{RT}$ & 1.52 & 0.39 & & 0.677 & 0.076 & $* *$ & 1.85 & 0.51 & & 46.28 & 9.78 & & $85 \%$ & $11 \%$ \\
\hline
\end{tabular}

t: $\mathrm{p}<0.05$ vs. $24 \mathrm{~h}$ incubation with the same concentration of MTA immediately followed by $\mathrm{RT}$; ${ }^{*}:$ moderate synergism $(0.7<\mathrm{Cl}<0.9)$; ${ }^{*}:$ synergism $(\mathrm{Cl}<0.7)$.

combination protocols, before starting triple treatment with irradiation.

The interaction between pemetrexed and gemcitabine was investigated using three different schemes (cfr. Methods). Simultaneous exposure to $24 \mathrm{~h}$ MTA and $24 \mathrm{~h} \mathrm{dFdC}$ resulted in a significantly higher $\mathrm{IC}_{50}$ value in both CAL-27 and A549 cells (e.g. for A549 $\mathrm{IC}_{50}$ for $24 \mathrm{~h} \mathrm{dFdC:} 3.64 \pm 0.27 \mathrm{nM}$; $\mathrm{IC}_{50}$ for $24 \mathrm{~h} \mathrm{dFdC}+24 \mathrm{~h}$ $200 \mathrm{nM}$ MTA: $7.48 \pm 1.48 \mathrm{nM}$ ) (table 3). The sequential exposure of cell lines to $24 \mathrm{~h}$ pemetrexed followed by $24 \mathrm{~h}$ gemcitabine caused an increase in the $\mathrm{IC}_{50}$ values too, which was significant for CAL-27 cells (e.g. $\mathrm{IC}_{50}$ for 24 h MTA: $119 \pm 16 \mathrm{nM}$; IC 50 for $24 \mathrm{~h}$ MTA $\rightarrow 24$ h 2 $\mathrm{nM}$ dFdC: $146 \pm 12 \mathrm{nM}$ ). In contrast, the inverted sequence induced a decrease in the $\mathrm{IC}_{50}$ value of MTA in CAL-27 cells ( $\mathrm{IC}_{50}$ for $24 \mathrm{~h}$ wash out $\rightarrow 24 \mathrm{~h}$ MTA: $198 \pm 15 \mathrm{nM} ; \mathrm{IC}_{50}$ for $24 \mathrm{~h} 2 \mathrm{nM} \mathrm{dFdC} \rightarrow 24$ h MTA: $132 \pm 15 \mathrm{nM})$. However, in A549 cells, $24 \mathrm{~h}$ gemcitabine followed by $24 \mathrm{~h}$ pemetrexed induced an increase in $\mathrm{IC}_{50}$ values in comparison with monotherapy with gemcitabine or pemetrexed alone. Calculation of the combination index (figure 3A, B, D, E) showed antagonistic interactions at the higher cytotoxic range. At fraction effects between 0.25 and 0.75 , all schedules (simultaneous and sequential) of $24 \mathrm{~h}$ gemcitabine and $24 \mathrm{~h}$ MTA demonstrated synergistic to additive effects in both CAL-27 and A549; however, though the differences were not marked, the sequence $24 \mathrm{~h} \mathrm{dFdC} \rightarrow 24 \mathrm{~h}$ MTA seemed to be the most effective treatment schedule.

The dose-effect curves of sequential combination of 1 $\mathrm{h} \mathrm{dFdC}$ and $24 \mathrm{~h} \mathrm{MTA}$ (figure 4) show that pemetrexed enhanced the growth inhibition of $1 \mathrm{~h}$ gemcitabine in both cell lines. Calculation of the $\mathrm{CI}$ value at fraction effects between 0.25 and 0.75 (figure 3C, F) revealed synergism in A549 cells, yet additivity in the CAL-27 


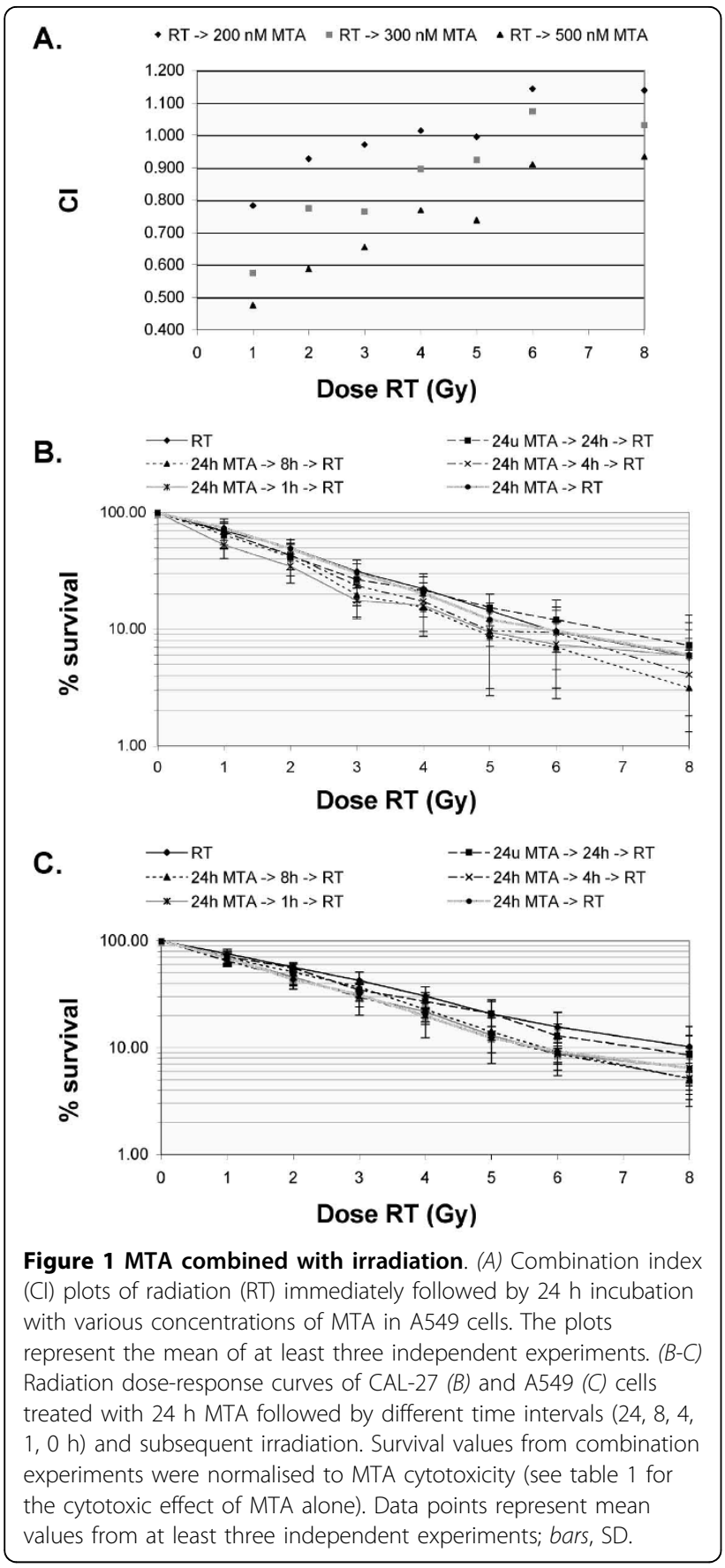

cell line. In contrast, the reverse sequence (i.e. $24 \mathrm{~h}$ MTA $\rightarrow 1 \mathrm{~h} \mathrm{dFdC)} \mathrm{induced} \mathrm{a} \mathrm{synergistic} \mathrm{interaction} \mathrm{in}$ both cell lines, with a significant decrease in $\mathrm{IC}_{50}$ values (table 3). For example, sequential exposure to $200 \mathrm{nM}$ MTA followed by $1 \mathrm{~h}$ gemcitabine considerably reduced the $\mathrm{IC}_{50}$ of $1 \mathrm{~h}$ gemcitabine from $569 \pm 97 \mathrm{nM}$ to $215 \pm$ $22 \mathrm{nM}$. Taking into account $\mathrm{IC}_{50}$ values calculated from the survival curves as well as the $\mathrm{CI}$ analysis for both CAL-27 and A549 cells, the degree of synergism obtained with the $24 \mathrm{~h}$ MTA $\rightarrow 1 \mathrm{~h} \mathrm{dFdC}$ sequence was
Table 2 Influence of $24 \mathrm{~h}$ MTA on the percentage cells in $G_{1}, S$ and $G_{2} / M$ phase

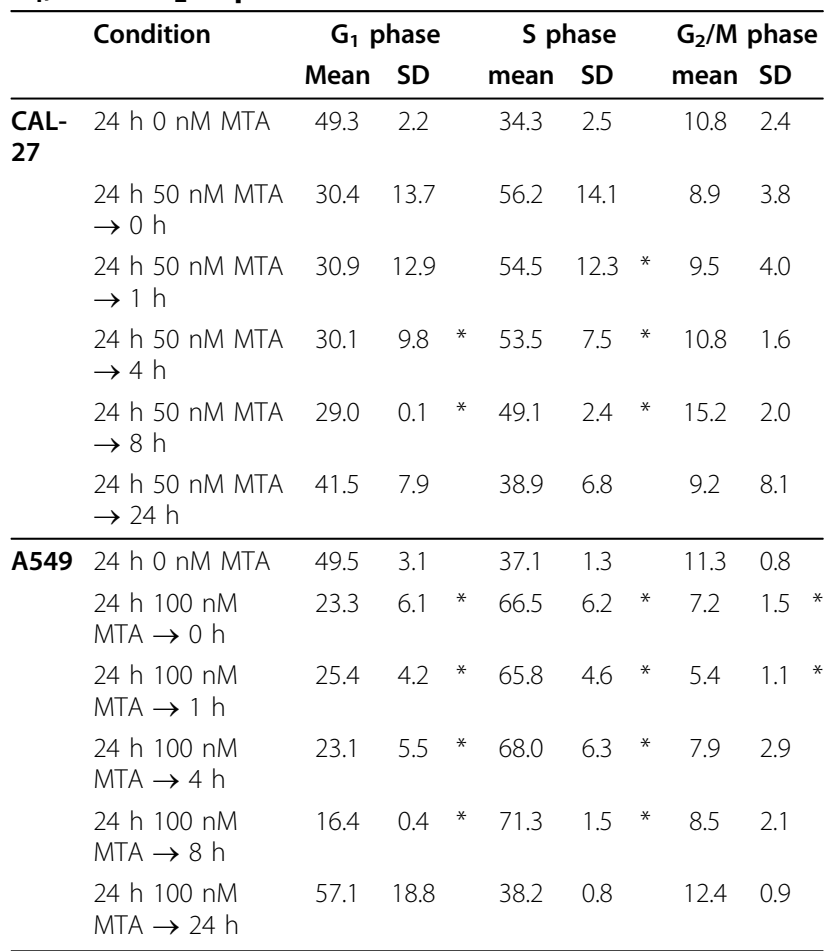

Cell cycle analysis was performed $0,1,4,8$ or $24 \mathrm{~h}$ after drug wash out. *: $\mathrm{p}<$ 0.05 vs. untreated control

remarkably greater than that observed with the other schedules investigated.

Combining pemetrexed with gemcitabine and irradiation CAL-27 and A549 cells were irradiated in combination with different schedules of pemetrexed and gemcitabine pretreatment. For all schedules included, treatment of the tumour cells with gemcitabine, pemetrexed and radiation produced growth inhibition that was additive to synergistic in comparison to monotherapy with gemcitabine, pemetrexed or irradiation alone (table 4). For example, simultaneous administration of MTA and $\mathrm{dFdC}$ for $24 \mathrm{~h}$ prior to irradiation resulted in CAL-27 and A549 cells in a dose enhancement factor of resp. $1.53 \pm 0.27$ and $1.49 \pm 0.28$. Both sequential schedules with $1 \mathrm{~h} \mathrm{dFdC}$ preceding or following $24 \mathrm{~h}$ MTA showed radiosensitising potential (DEF 1.29-1.56), with CI values indicating moderate synergism in CAL-27 cells and synergism in A549 cells. Especially 24 h MTA followed by $1 \mathrm{~h} \mathrm{dFdC}$ and irradiation seemed interesting to us, since this scheme resulted in DEFs around 1.50 in both cell lines. Moreover, the percentage of growth inhibition induced by this drug combination (survival rate $65 \pm 11 \%$ for CAL-27; $49 \pm 8 \%$ for A549) was significantly lower than the cytotoxic effect of MTA alone and that of $\mathrm{dFdC}$ alone. This can be explained by the 


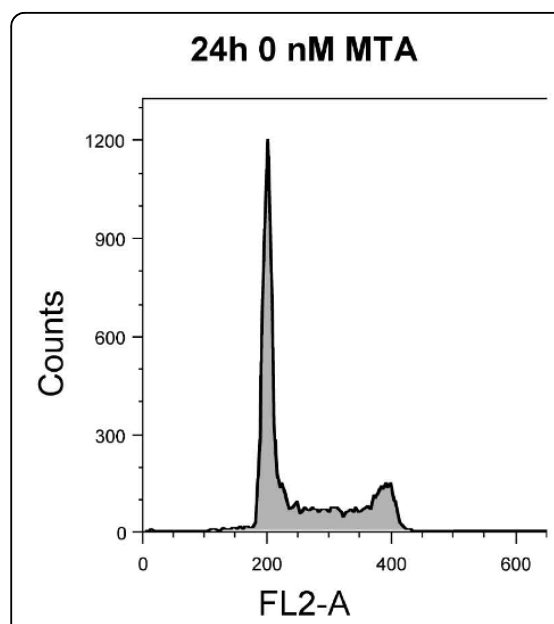

24h $100 \mathrm{nM}$ MTA $\rightarrow$ 4h

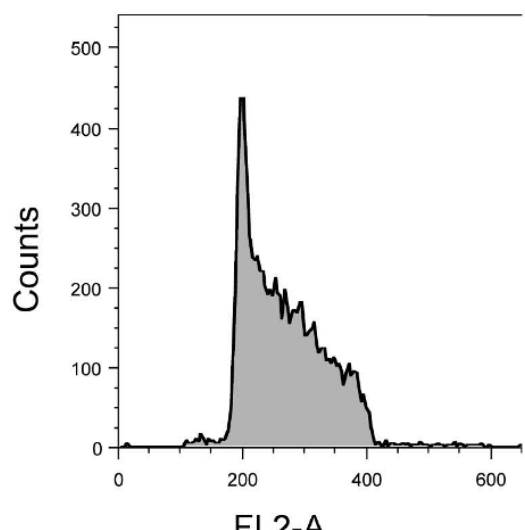

FL2-A

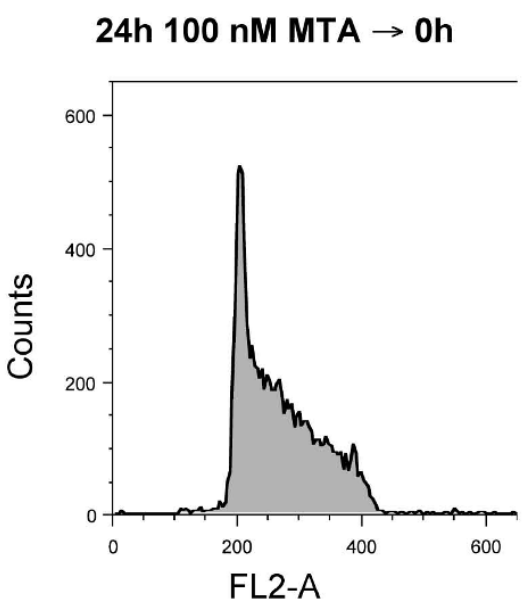

24h $100 \mathrm{nM}$ MTA $\rightarrow$ 8h

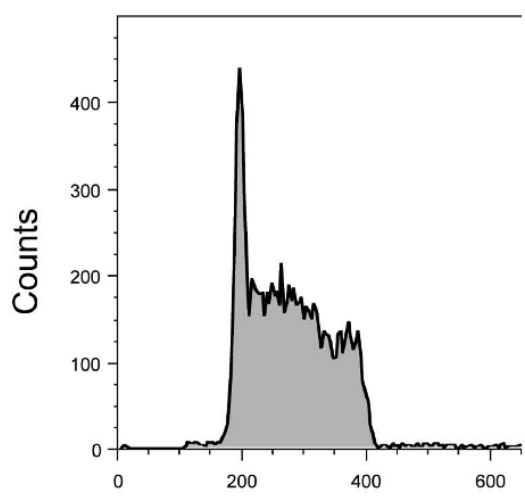

FL2-A

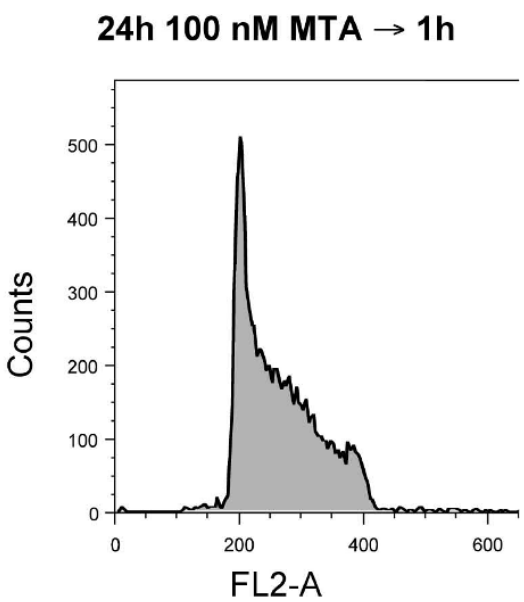

24h $100 \mathrm{nM}$ MTA $\rightarrow$ 24h

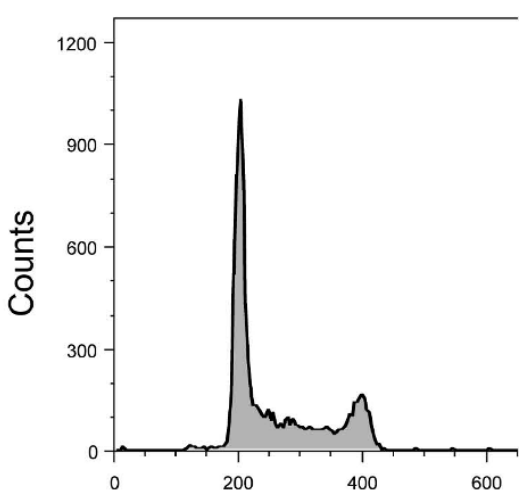

FL2-A

Figure 2 Influence of MTA on cell cycle distribution. DNA histograms of A549 cells at different time points after $24 \mathrm{~h}$ incubation with 100 NM MTA.

synergistic interaction observed with the $24 \mathrm{~h}$ MTA $\rightarrow 1$ h dFdC combination (without radiotherapy).

\section{Discussion}

Today, the mainstay of cancer treatments consists of surgery, radiotherapy and/or chemotherapy. In daily practice, the combination of radiotherapy and chemotherapy has become a standard treatment and it is associated with improved survival rates in many tumours, thereby favouring multimodal strategies in tumour therapy. A multitude of potential interaction mechanisms between radiotherapy and chemotherapy, including radiosensitisation of tumour cells through drug exposure, may improve treatment results [38]. Given the reported radiosensitising potential of both gemcitabine [39] and pemetrexed [23], this paper, for the first time, describes a preclinical study evaluating the triple combination of pemetrexed, gemcitabine and irradiation.
Concentration-dependent growth inhibition by single agent treatment with gemcitabine or pemetrexed was observed in both A549 lung carcinoma and CAL-27 head and neck carcinoma cell lines, with $\mathrm{IC}_{50}$ values $<1.0 \mu \mathrm{M}$ in all cases, which is well below the mean peak plasma concentration of both drugs achievable in patients $[40,41]$.

The interaction between pemetrexed and irradiation was examined as a potential strategy to enhance the therapeutic ratio of combined-modality cancer treatment. However, incubation of CAL-27 or A549 cells with $24 \mathrm{~h}$ pemetrexed immediately preceding or following irradiation (0-8 Gy) was unable to produce any significant radiosensitisation of the tumour cells. In contrast, Bischof et al demonstrated that a concomitant exposure to ionising radiation and moderately toxic concentrations of pemetrexed (106 nM, 70\% survival) inhibited clonogenic survival in excess of independent toxicities in all four human tumour carcinoma cell lines 
Table $3 \mathrm{IC}_{50}$ and combination index (CI) values for MTA - dFdC combinations in CAL-27 and A549 cells

\begin{tabular}{|c|c|c|c|c|c|c|c|c|c|c|c|c|}
\hline \multirow[t]{2}{*}{ Condition } & \multicolumn{6}{|c|}{ CAL-27 } & \multicolumn{5}{|c|}{ A549 } & \\
\hline & $\mathrm{IC}_{50}(\mathrm{nM})$ & SD & & $\mathrm{Cl}$ & SD & & $\mathrm{IC}_{50}(\mathrm{nM})$ & SD & & $\mathrm{Cl}$ & SD & \\
\hline 24 h MTA $\rightarrow 24$ h wash out & 118.53 & 16.37 & & & & & 569.47 & 120.60 & & & & \\
\hline 24 h wash out $\rightarrow 24$ h MTA & 198.25 & 14.51 & & & & & 1576.86 & 349.19 & & & & \\
\hline 24 h MTA +24 h 2 nM dFdC $\rightarrow 24$ h wash out & 147.44 & 18.68 & & 1.038 & 0.378 & & 1689.43 & 1289.82 & & 1.003 & 0.352 & \\
\hline 24 h MTA +24 h 4 nM dFdC $\rightarrow 24$ h wash out & 240.31 & 49.10 & t & 0.957 & 0.510 & & 9120.46 & 1499.06 & t & 0.569 & 0.271 & ** \\
\hline 24 h MTA $\rightarrow 24$ h 2 nM dFdC & 146.31 & 12.08 & t & 0.943 & 0.403 & & 452.53 & 177.35 & & 0.632 & 0.213 & $* *$ \\
\hline 24 h MTA $\rightarrow 24$ h 4 nM dFdC & 130.60 & 29.92 & & 0.858 & 0.461 & * & 1069.95 & 1035.22 & & 0.373 & 0.190 & $* *$ \\
\hline $24 \mathrm{~h} 2 \mathrm{nM} \mathrm{dFdC} \rightarrow 24 \mathrm{~h} \mathrm{MTA}$ & 132.00 & 14.59 & † & 0.779 & 0.341 & * & 1322.54 & 833.14 & & 0.546 & 0.237 & $* *$ \\
\hline 24 h 4 nM dFdC $\rightarrow 24$ h MTA & 172.68 & 42.09 & & 0.739 & 0.373 & * & 6076.56 & 3648.50 & & 0.384 & 0.154 & ** \\
\hline $24 \mathrm{~h} \mathrm{dFdC} \rightarrow 24 \mathrm{~h}$ wash out & 4.35 & 0.39 & & & & & 3.64 & 0.27 & & & & \\
\hline $24 \mathrm{~h}$ wash out $\rightarrow 24 \mathrm{~h} \mathrm{dFdC}$ & 5.87 & 0.17 & & & & & 5.30 & 0.20 & & & & \\
\hline 24 h dFdC +24 h 50 nM MTA $\rightarrow 24$ h wash out & 4.25 & 0.37 & & 1.141 & 0.858 & & & & & & & \\
\hline 24 h dFdC +24 h 100 nM MTA $\rightarrow 24$ h wash out & 5.82 & 0.68 & t & 1.201 & 0.843 & & & & & & & \\
\hline 24 h dFdC +24 h 200 nM MTA $\rightarrow 24$ h wash out & & & & & & & 7.48 & 1.04 & t & 1.112 & 0.972 & \\
\hline 24 h dFdC +24 h 500 nM MTA $\rightarrow 24$ h wash out & & & & & & & 19.40 & 11.06 & & 1.167 & 0.967 & \\
\hline $24 \mathrm{~h} \mathrm{dFdC} \rightarrow 24 \mathrm{~h} 50 \mathrm{nM}$ MTA & 3.83 & 0.07 & & 1.073 & 0.872 & & & & & & & \\
\hline $24 \mathrm{~h} \mathrm{dFdC} \rightarrow 24$ h 100 nM MTA & 3.61 & 0.20 & & 1.179 & 1.071 & & & & & & & \\
\hline 24 h dFdC $\rightarrow 24$ h 200 nM MTA & & & & & & & 4.90 & 1.79 & & 0.873 & 0.924 & * \\
\hline 24 h dFdC $\rightarrow 24$ h 500 nM MTA & & & & & & & 7.08 & 1.87 & & 0.921 & 0.942 & \\
\hline 24 h 50 nM MTA $\rightarrow 24$ h dFdC & 4.88 & 0.29 & t & 0.961 & 0.591 & & & & & & & \\
\hline $24 \mathrm{~h} 100 \mathrm{nM}$ MTA $\rightarrow 24 \mathrm{~h}$ dFdC & 5.89 & 0.83 & & 1.158 & 0.870 & & & & & & & \\
\hline 24 h 200 nM MTA $\rightarrow 24$ h dFdC & & & & & & & 6.96 & 2.52 & & 0.830 & 0.848 & * \\
\hline 24 h 500 nM MTA $\rightarrow 24$ h dFdC & & & & & & & 14.81 & 10.54 & & 0.838 & 0.806 & * \\
\hline $1 \mathrm{~h} \mathrm{dFdC} \rightarrow 24 \mathrm{~h}$ wash out & 478.76 & 149.90 & & & & & 533.46 & 197.64 & & & & \\
\hline $24 \mathrm{~h}$ wash out $\rightarrow 1 \mathrm{~h} \mathrm{dFdC}$ & 495.55 & 130.97 & & & & & 569.36 & 96.66 & & & & \\
\hline $1 \mathrm{~h} \mathrm{dFdC} \rightarrow 24$ h 50 nM MTA & 571.61 & 262.49 & & 1.154 & 0.349 & & & & & & & \\
\hline $1 \mathrm{~h} \mathrm{dFdC} \rightarrow 24 \mathrm{~h} 100 \mathrm{nM}$ MTA & 386.35 & 92.33 & & 0.980 & 0.185 & & & & & & & \\
\hline $1 \mathrm{~h} \mathrm{dFdC} \rightarrow 24$ h 200 nM MTA & & & & & & & 421.84 & 237.54 & & 0.693 & 0.287 & ** \\
\hline $1 \mathrm{~h} \mathrm{dFdC} \rightarrow 24$ h 500 nM MTA & & & & & & & 407.32 & 187.49 & & 0.570 & 0.265 & ** \\
\hline 24 h 50 nM MTA $\rightarrow 1$ h dFdC & 271.36 & 38.36 & & 0.880 & 0.466 & * & & & & & & \\
\hline $24 \mathrm{~h} 100 \mathrm{nM} \mathrm{MTA} \rightarrow 1 \mathrm{~h} \mathrm{dFdC}$ & 166.12 & 16.64 & t & 0.803 & 0.413 & * & & & & & & \\
\hline 24 h 200 nM MTA $\rightarrow 1$ h dFdC & & & & & & & 215.44 & 21.72 & t & 0.880 & 0.682 & * \\
\hline $24 \mathrm{~h} 500$ nM MTA $\rightarrow 1$ h dFdC & & & & & & & 217.14 & 24.80 & t & 0.681 & 0.494 & ** \\
\hline
\end{tabular}

t: $\mathrm{p}<0.05$ vs. $\mathrm{I}_{50}$ of the corresponding drug alone; *: moderate synergism $(0.7<\mathrm{Cl}<0.9) ;{ }^{* *}$ : synergism $(\mathrm{Cl}<0.7)$.

tested, with enhancement ratios ranging from 1.2 (HeLa cervix carcinoma and MCF-7 breast carcinoma cells) to 1.6 (LXI lung carcinoma cells). In WiDr colon carcinoma cells, significant radiosensitisation (DEF 1.8) was only noticed at higher pemetrexed concentrations (636 nM, 85\% survival), with a DEF of 1.1 when cells were pretreated with $106 \mathrm{nM}$ pemetrexed (no cytotoxic effect) [23].

As the timing of irradiation relative to drug application may play an important role in combined modality treatments, tumour cells were irradiated at different time intervals between $24 \mathrm{~h}$ pemetrexed treatment and irradiation. Overall, including a time interval between pemetrexed exposure and irradiation seemed favourable to pemetrexed immediately preceding or following radiotherapy, with DEFs up to 1.6 for CAL-27 cells. No readily observable tendency in cell killing was shown over the different time intervals. For both CAL-27 and A549 cells, a $1 \mathrm{~h}$ time interval resulted in a clear radiosensitising effect (DEF 1.5). Similarly, no substantial variation in survival fraction could be observed in WiDr colon carcinoma cells when the interval between the 


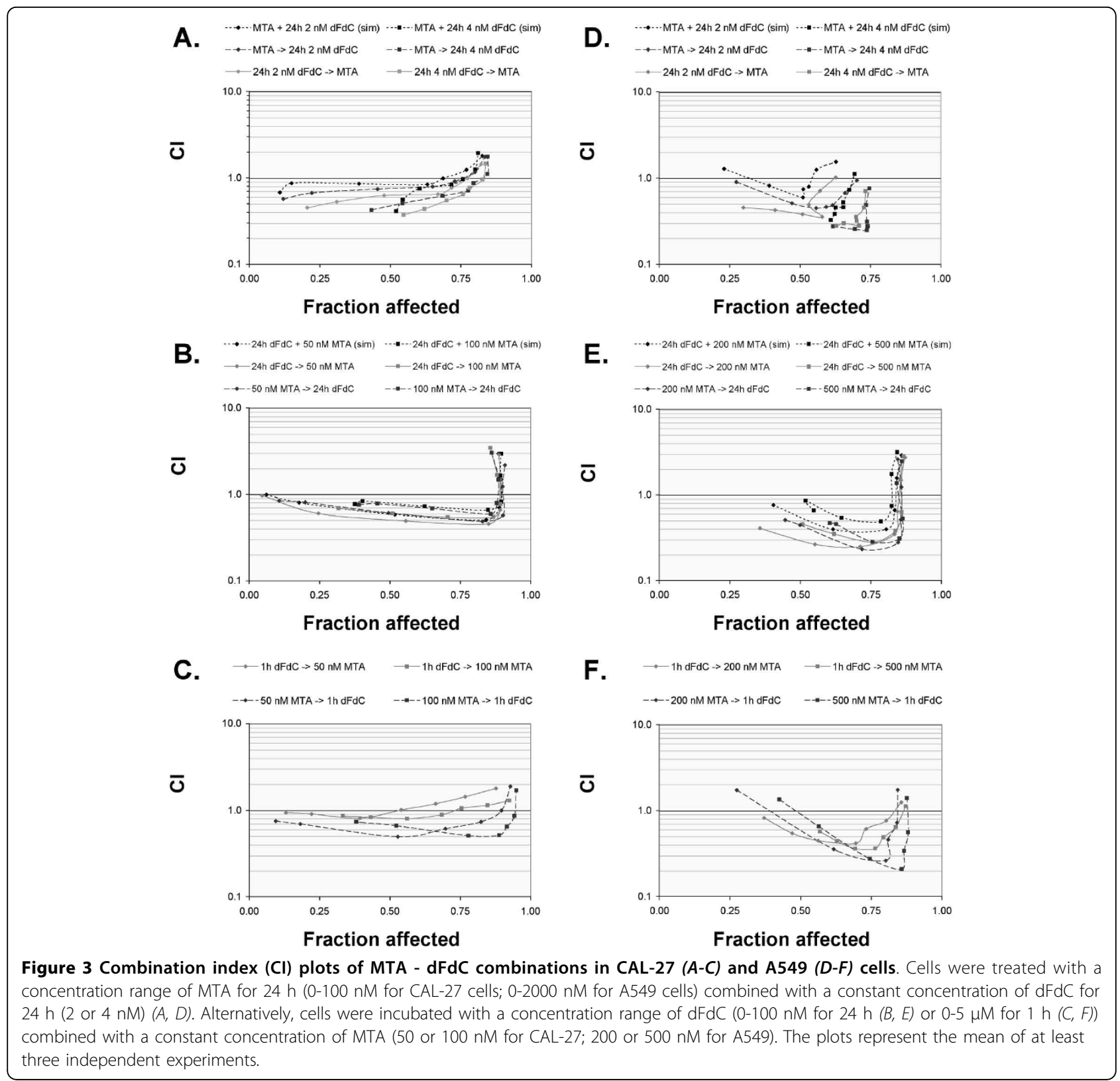

start of $2 \mathrm{~h}$ pemetrexed exposure and irradiation was varied from $-4 \mathrm{~h}$ to $+10 \mathrm{~h}$ [23]. This finding led to the hypothesis that pemetrexed possibly exerts its radiosensitising potential very rapidly and that this effect pertains after drug removal for an extended period of time (at least 8 hours). Interestingly, a different behavior has been reported for gemcitabine, where the radiosensitising potential gradually decreased with an increasing time interval [34].

Our findings in CAL-27 and A549 cells, showing S phase accumulation when cells were treated with only slightly toxic concentrations of pemetrexed for $24 \mathrm{~h}$, are consistent with previous data in the A549 cell line
$[22,42]$. The $\mathrm{S}$ phase accumulation was observed for up to $8 \mathrm{~h}$ after drug removal, yet disappeared after $24 \mathrm{~h}$ wash out. This implies that the differences in radiosensitisation could not be explained by the pemetrexedinduced $S$ phase accumulation (see also table 1 and 2). Correspondingly, the study by Bischof et al also excluded the $S$ phase enrichment as the primary mechanism for radiosensitisation by pemetrexed [23]. Moreover, tumour cell apoptosis was not found to be responsible for pemetrexed-induced radiosensitisation in human colon carcinoma cells [43]. Thus, the differential radiosensitisation induced by pemetrexed cannot be explained at present. A number of causes appear 


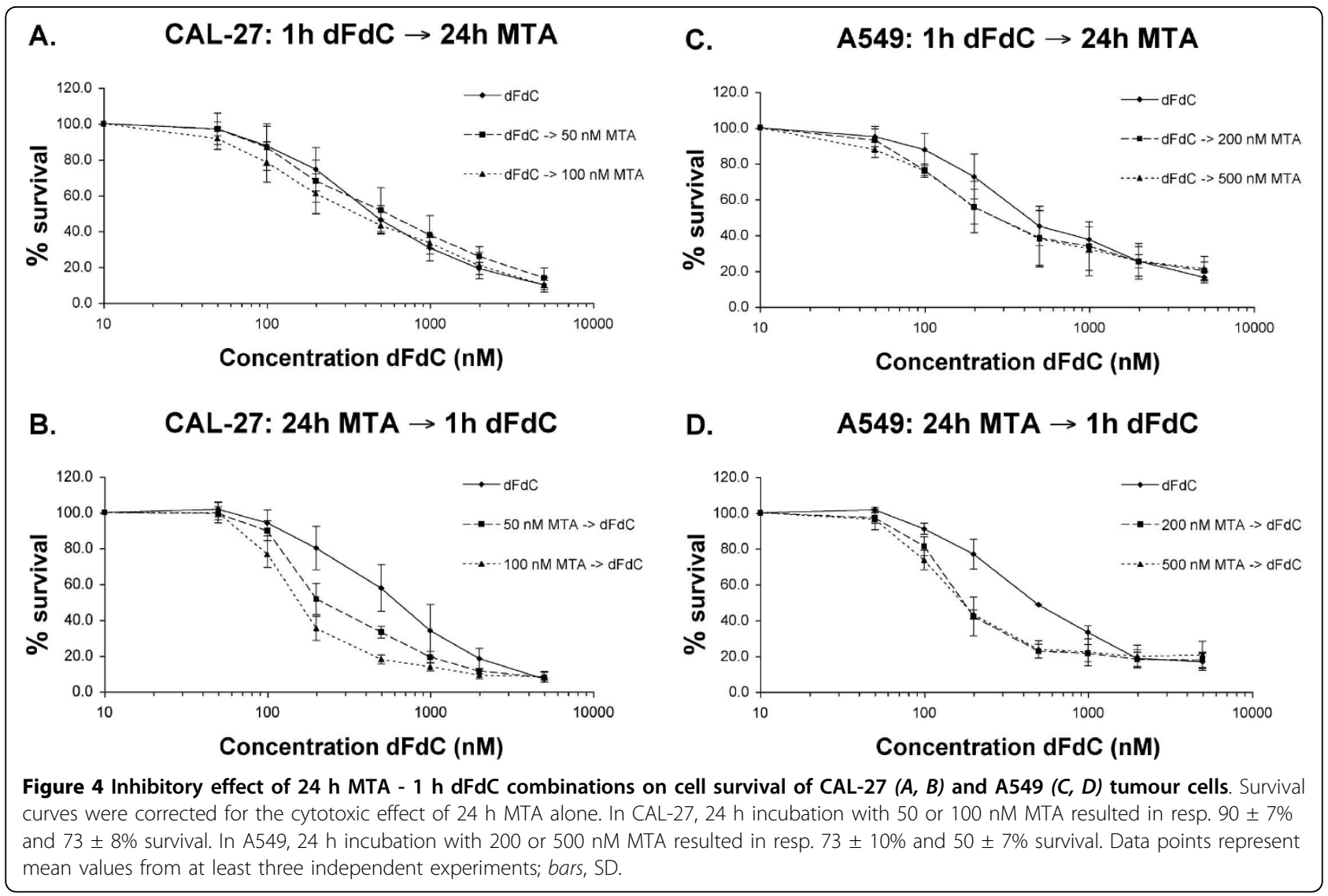

conceivable (such as differences in drug toxicity levels, growth characteristics of the cell lines investigated, levels of drug-inhibited enzymes, or intracellular pemetrexed polyglutamation), and further assessment of the molecular mechanisms underlying the radiosensitising potential of pemetrexed seems crucial.

Our study aimed at investigating the triple combination of gemcitabine, pemetrexed and irradiation. However, a recommended protocol for gemcitabine/ pemetrexed combinations differed among previously published in vitro studies and there was generally no agreement with regard to the preferable treatment schedule. The drug combination has been examined in vitro with different human tumour cell lines (including colon, bladder and pancreatic cancer, NSCLC, and malignant pleural mesothelioma), resulting in controversial schedule-dependent interactions. Though simultaneous drug administration is the more frequently used and most practical clinical regimen, results from the present and previous in vitro studies showed that simultaneous exposure to these two antimetabolites did not significantly increase cell kill and thus probably will not improve the clinical therapeutic effect $[42,44,45]$. Conversely, we observed that sequential exposure produced a greater cytotoxic effect than that exerted by single- agent use or simultaneous exposure. In particular, as shown by the $\mathrm{IC}_{50}$ values calculated from survival curves as well as the results from CI analysis in both A549 and CAL-27 cells, a higher synergistic interaction was obtained by pretreatment with $24 \mathrm{~h}$ pemetrexed followed by $1 \mathrm{~h}$ gemcitabine ( $24 \mathrm{~h}$ MTA $\rightarrow 1 \mathrm{~h} \mathrm{dFdC)}$ in comparison with the other schedules investigated. These findings are in agreement with previous reported observations in the A549 NSCLC cell line by Giovannetti et al $[22,30]$; for the CAL-27 SCCHN cell line, no previous data are available. In the clinic, a phase I trial in patients with advanced solid tumours suggested that the sequence of gemcitabine administered on days 1 and 8 with pemetrexed administered on day 8,90 minutes after gemcitabine was well tolerated and recommended for further study [46]. However, a few years later, the same research group conducted a phase II trial of three schedules of pemetrexed and gemcitabine as front-line therapy for advanced NSCLC. In this trial, the pemetrexed-gemcitabine schedule was less toxic compared with other sequences and, by obtaining a confirmed response rate of $31 \%$, was the only schedule that met the protocol-defined efficacy criteria [47]. As such, both preclinical and clinical data support the sequential pemetrexed-gemcitabine schedule in NSCLC. 
Table 4 DEF, $\mathrm{Cl}_{1} \mathrm{ID}_{50}, \mathrm{SF}_{2}$ and \% survival (representing the cytotoxic effect of treatment with MTA and/or dFdC alone, $0 \mathrm{~Gy}$ ) for MTA - dFdC - irradiation (RT) combinations in CAL-27 and A549 cells

\begin{tabular}{|c|c|c|c|c|c|c|c|c|c|c|c|c|c|c|c|c|}
\hline & Condition & & DEF & & & $\mathrm{Cl}$ & & & $D_{50}$ & & & $\mathrm{SF}_{2}$ & & $\%$ & surviva & \\
\hline & & mean & SD & & mean & SD & & mean & SD & & mean & SD & & mean & SD & \\
\hline CAL-27 & RT & & & & & & & 1.94 & 0.47 & & 48.37 & 9.31 & & $100 \%$ & $0 \%$ & \\
\hline & 24 h 50 nM MTA $\rightarrow$ RT & 1.04 & 0.23 & & 1.095 & 0.127 & & 1.97 & 0.45 & & 49.25 & 9.71 & & $97 \%$ & $11 \%$ & \\
\hline & $24 \mathrm{~h} 50 \mathrm{nM}$ MTA $\rightarrow 24 \mathrm{~h} \rightarrow$ RT & 1.59 & 0.53 & & 0.916 & 0.063 & & 1.71 & 0.66 & & 43.37 & 12.35 & & $70 \%$ & $21 \%$ & \\
\hline & $24 \mathrm{~h} 50 \mathrm{nM} \mathrm{MTA} \rightarrow 1 \mathrm{~h} \rightarrow \mathrm{RT}$ & 1.46 & 0.21 & & 0.933 & 0.073 & & 1.21 & 0.35 & & 32.45 & 8.43 & & $98 \%$ & $4 \%$ & \\
\hline & $24 \mathrm{~h} 2 \mathrm{nM} \mathrm{dFdC} \rightarrow \mathrm{RT}$ & 1.47 & 0.09 & & 0.888 & 0.180 & * & 1.72 & 0.10 & & 49.25 & 9.71 & & $96 \%$ & $1 \%$ & \\
\hline & $24 \mathrm{~h} 2 \mathrm{nM} \mathrm{dFdC} \rightarrow 24 \mathrm{~h} \rightarrow \mathrm{RT}$ & 1.04 & 0.16 & & 1.090 & 0.101 & & 2.43 & 0.08 & & 58.31 & 2.96 & & $84 \%$ & $18 \%$ & \\
\hline & $1 \mathrm{~h} 100 \mathrm{nM} \mathrm{dFdC} \rightarrow 24 \mathrm{~h} \rightarrow \mathrm{RT}$ & 1.56 & 0.46 & & 0.653 & 0.108 & ** & 1.32 & 0.25 & & 34.09 & 5.34 & & $91 \%$ & $24 \%$ & \\
\hline & $1 \mathrm{~h} 50 \mathrm{nM} \mathrm{dFdC} \rightarrow \mathrm{RT}$ & 1.07 & 0.19 & & 0.917 & 0.124 & & 1.69 & 0.64 & & 44.73 & 14.77 & & $98 \%$ & $14 \%$ & \\
\hline & 24 h 2 nM dFdC +24 h 50 nM MTA $\rightarrow$ RT & 1.53 & 0.27 & $\dagger$ & 0.960 & 0.267 & & 1.66 & 0.09 & & 42.27 & 1.03 & & $98 \%$ & $11 \%$ & \\
\hline & 24 h 2 nM dFdC $\rightarrow 24$ h 50 nM MTA $\rightarrow$ RT & 1.38 & 0.09 & & 0.949 & 0.106 & & 1.85 & 0.34 & & 46.93 & 6.81 & & $75 \%$ & $4 \%$ & $\dagger$ \\
\hline & 24 h 50 nM MTA $\rightarrow 24$ h 2 nM dFdC $\rightarrow$ RT & 1.78 & 0.14 & & 0.705 & 0.097 & * & 1.42 & 0.06 & & 36.83 & 3.36 & & $64 \%$ & $22 \%$ & \\
\hline & $1 \mathrm{~h} 100 \mathrm{nM} \mathrm{dFdC} \rightarrow 24$ h $50 \mathrm{nM}$ MTA $\rightarrow$ RT & 1.56 & 0.37 & t & 0.801 & 0.094 & * & 1.29 & 0.20 & + & 34.65 & 4.07 & t & $71 \%$ & $15 \%$ & $\dagger$ \\
\hline & 24 h 50 nM MTA $\rightarrow 1$ h 50 nM dFdC $\rightarrow$ RT & 1.43 & 0.57 & & 0.858 & 0.175 & * & 1.30 & 0.45 & & 34.93 & 10.25 & & $65 \%$ & $11 \%$ & t;t† \\
\hline A549 & RT & & & & & & & 2.41 & 0.39 & & 56.26 & 6.18 & & $100 \%$ & $0 \%$ & \\
\hline & $24 \mathrm{~h} 100 \mathrm{nM}$ MTA $\rightarrow$ RT & 1.29 & 0.25 & & 0.674 & 0.053 & ** & 1.77 & 0.36 & & 45.39 & 7.15 & & $87 \%$ & $11 \%$ & \\
\hline & $24 \mathrm{~h} 100 \mathrm{nM}$ MTA $\rightarrow 24 \mathrm{~h} \rightarrow \mathrm{RT}$ & 0.98 & 0.15 & & 0.838 & 0.070 & * & 2.16 & 0.11 & & 52.70 & 2.00 & & $84 \%$ & $16 \%$ & \\
\hline & $24 \mathrm{~h} 100 \mathrm{nM} \mathrm{MTA} \rightarrow 1 \mathrm{~h} \rightarrow$ RT & 1.52 & 0.39 & & 0.681 & 0.084 & ** & 1.85 & 0.51 & & 46.28 & 9.78 & & $85 \%$ & $11 \%$ & \\
\hline & $24 \mathrm{~h} 2 \mathrm{nM} \mathrm{dFdC} \rightarrow \mathrm{RT}$ & 1.55 & 0.24 & & 0.538 & 0.057 & ** & 1.25 & 0.08 & & 34.55 & 2.01 & & $71 \%$ & $16 \%$ & \\
\hline & $24 \mathrm{~h} 2 \mathrm{nM} \mathrm{dFdC} \rightarrow 24 \mathrm{~h} \rightarrow \mathrm{RT}$ & 0.99 & 0.31 & & 0.703 & 0.118 & * & 2.04 & 0.40 & & 50.19 & 6.96 & & $65 \%$ & $4 \%$ & \\
\hline & $1 \mathrm{~h} 100 \mathrm{nM} \mathrm{dFdC} \rightarrow 24 \mathrm{~h} \rightarrow \mathrm{RT}$ & 1.23 & 0.23 & & 0.606 & 0.073 & ** & 1.97 & 0.24 & & 49.28 & 4.36 & & $67 \%$ & $13 \%$ & \\
\hline & 1 h 50 nM dFdC $\rightarrow$ RT & 1.49 & 0.39 & & 0.831 & 0.068 & * & 1.92 & 0.49 & & 47.99 & 8.72 & & $96 \%$ & $5 \%$ & \\
\hline & 24 h 2 nM dFdC +24 h 100 nM MTA $\rightarrow$ RT & 1.49 & 0.28 & & 0.564 & 0.075 & $* *$ & 1.32 & 0.30 & & 36.11 & 6.47 & & $66 \%$ & $23 \%$ & \\
\hline & 24 h 2 nM dFdC $\rightarrow 24$ h 100 nM MTA $\rightarrow$ RT & 0.94 & 0.27 & & 0.585 & 0.101 & ** & 2.21 & 0.80 & & 52.39 & 11.98 & & $47 \%$ & $14 \%$ & \\
\hline & 24 h 100 nM MTA $\rightarrow 24$ h 2 nM dFdC $\rightarrow$ RT & 1.17 & 0.24 & & 0.500 & 0.073 & ** & 1.69 & 0.36 & & 44.34 & 7.16 & & $48 \%$ & $16 \%$ & $\dagger$ \\
\hline & $1 \mathrm{~h} 100 \mathrm{nM} \mathrm{dFdC} \rightarrow 24$ h 100 nM MTA $\rightarrow$ RT & 1.29 & 0.27 & & 0.513 & 0.053 & $* *$ & 1.88 & 0.25 & & 47.68 & 4.45 & & $48 \%$ & $12 \%$ & $\dagger$ \\
\hline & $24 \mathrm{~h} 100 \mathrm{nM} \mathrm{MTA} \rightarrow 1$ h $50 \mathrm{nM} \mathrm{dFdC} \rightarrow$ RT & 1.52 & 0.58 & & 0.534 & 0.083 & $* *$ & 1.92 & 0.50 & & 47.93 & 9.71 & & $49 \%$ & $8 \%$ & †;†十 \\
\hline
\end{tabular}

t: $\mathrm{p}<0.05$ vs. corresponding schedule of MTA and RT; $\mathrm{tt}: \mathrm{p}<0.05$ vs. corresponding schedule of $\mathrm{dFdC}$ and $\mathrm{RT}$; *: moderate synergism $(0.7<\mathrm{Cl}<0.9) ; * *$ : synergism $(\mathrm{Cl}<0.7)$

Concerning the molecular basis for pemetrexed-gemcitabine interactions, it has been suggested that the favourable modulation of the cell cycle by pemetrexed may be considered as one of the most important mechanisms underlying the synergistic interaction in the 24 h MTA $\rightarrow 1 \mathrm{~h} \mathrm{dFdC} \mathrm{sequence} \mathrm{[22].} \mathrm{Because} \mathrm{gemcita-}$ bine is an $\mathrm{S}$ phase specific drug, the increase in its activity in this schedule may be the result of the $S$ phase accumulation induced by pemetrexed, which potentially facilitates incorporation of 2 ',2'-difluoro-deoxycytidine triphosphate into the DNA. As the cell cycle modulation by pemetrexed lasted for several hours after drug removal, but disappeared after $24 \mathrm{~h}$, this may explain why the $24 \mathrm{~h}$ MTA $\rightarrow 1 \mathrm{~h} \mathrm{dFdC}$ seems preferable to the 24 h MTA $\rightarrow 24$ h dFdC schedule.
In A549 cells, it has been demonstrated that pemetrexed, at its $\mathrm{IC}_{50}$ and $\mathrm{IC}_{75}$ levels, significantly upregulated the hENT1 carrier, potentially facilitating gemcitabine cytotoxicity [22]. Moreover, being an inhibitor of de novo purine biosynthesis (because of the blockade of the key enzyme GARFT), pemetrexed was shown to increase the expression of $\mathrm{dCK}$ as a compensatory mechanism [22]. The dCK activity of untreated A549 and CAL-27 cells was reported to be highly comparable (resp. 6.02 and $5.02 \mathrm{nmol} / \mathrm{h} / \mathrm{mg}$ protein) and a weak positive correlation between $\mathrm{dCK}$ activity and the radiosensitising effect of gemcitabine has been reported [48], suggesting that enhancement of hENT1 and dCK expression by pemetrexed in the pemetrexed $\rightarrow$ gemcitabine sequence strongly supports this combination. 
In addition, several studies showed that TS expression is significantly correlated with pemetrexed sensitivity both in a preclinical and clinical setting [22,49]. Functional inactivity and mutations of p53 were shown to differentially affect the expression and activity of TS [50], potentially influencing the response of A549 (wt p53) and CAL-27 (mt p53) cells to pemetrexed-based treatment. Nevertheless, different conclusions regarding the relationship between functional p53 status and sensitivity to pemetrexed have been obtained, possibly depending on the phenotypic/genotypic background of the model system used [29,51-53]. Similarly, the role of p53 on the ability of gemcitabine to induce a cytotoxic and radiosensitising effect is not yet completely elucidated $[6,54,55]$, making further mechanistic unravelling of the pemetrexed-gemcitabine-radiation combination highly warranted.

When combining pemetrexed and gemcitabine with irradiation, the $24 \mathrm{~h} \mathrm{MTA} \rightarrow 1 \mathrm{~h} d F d C \rightarrow \mathrm{RT}$ regimen showed radiosensitising potential in both cell lines (DEF 1.4 for CAL-27; 1.5 for A549). Other pemetrexed/gemcitabine schedules in combination with radiation also produced additive to synergistic growth inhibition in comparison to monotherapy, and the corresponding DEFs were not significantly different from these obtained with $24 \mathrm{~h} \mathrm{MTA} \rightarrow 1 \mathrm{~h} \mathrm{dFdC} \rightarrow \mathrm{RT}$. However, given the synergistic interaction between $24 \mathrm{~h}$ pemetrexed and $1 \mathrm{~h}$ gemcitabine, the $24 \mathrm{~h} \mathrm{MTA} \rightarrow 1 \mathrm{~h} \mathrm{dFdC} \rightarrow$ RT turned out to be the preferred schedule for combined administration with radiotherapy in our preclinical model system.

\section{Conclusions}

This study characterises, for the first time, the interactions between gemcitabine, pemetrexed and radiotherapy. Preliminary results from our in vitro model suggest that the sequence $24 \mathrm{~h} \mathrm{MTA} \rightarrow 1 \mathrm{~h} \mathrm{dFdC} \rightarrow \mathrm{RT}$ is the most rational design. Further in depth mechanistic unravelling of the pemetrexed-gemcitabine-radiation combination is certainly needed. As extrapolation of in vitro data to the clinic should be considered with caution, the experiments provide a strong experimental basis for future development of this triple combination in an in vivo setting.

\section{Acknowledgements \\ AW holds a PhD fellowship and BP a post-doc fellowship of the Fund for Scientific Research, Flanders, Belgium (FWO-F).}

\section{Author details \\ ${ }^{1}$ Laboratory of Cancer Research and Clinical Oncology, Department of Medical Oncology, University of Antwerp, Universiteitsplein 1, 2610 Wilrijk, Belgium. ${ }^{2}$ Department of Radiotherapy, University Radiotherapy Antwerp (URA), Lindendreef 1, 2020 Antwerp, Belgium.}

\section{Authors' contributions}

AW participated in the design of the study, performed the experiments and the statistical analysis and drafted the manuscript. GP and $\mathrm{HL}$ participated in the cell survival experiments and performed cell culture. MB participated in the acquisition of data. PM was involved in the irradiation experiments. BP, $\mathrm{FL}$ and JBV participated in the conception, design, and coordination of the study, and revised the manuscript critically. All authors read and approved the final manuscript.

\section{Competing interests}

The authors declare that they have no competing interests. Pemetrexed and gemcitabine were kindly provided by Eli Lilly (Indianapolis, USA).

Received: 26 October 2009 Accepted: 19 August 2010

Published: 19 August 2010

\section{References}

1. Seiwert TY, Salama JK, Vokes EE: The concurrent chemoradiation paradigm-general principles. Nat Clin Pract Oncol 2007, 4:86-100.

2. Peters GJ, van der Wilt CL, Van Moorsel CJA, Kroep JR, Bergman AM, Ackland SP: Basis for effective combination cancer chemotherapy with antimetabolites. Pharmacol Ther 2000, 87:227-253.

3. Mackey JR, Mani RS, Selner M, Mowles D, Young JD, Belt JA, Crawford CR, Cass CE: Functional nucleoside transporters are required for gemcitabine influx and manifestation of toxicity in cancer cell lines. Cancer Res 1998, 58:4349-4357.

4. Huang P, Chubb S, Hertel LW, Grindey GB, Plunkett W: Action of 2',2'difluorodeoxycytidine on DNA synthesis. Cancer Res 1991, 51:6110-6117.

5. Pauwels B, Korst A, Lardon F, Vermorken J: Combined modality therapy of gemcitabine and radiation. Oncologist 2005, 10:34-51.

6. Robinson BW, Shewach DS: Radiosensitization by gemcitabine in p53 wild-type and mutant MCF-7 breast carcinoma cell lines. Clin Cancer Res 2001, 7:2581-2589.

7. Morgan M, Parsels L, Parsels J, Mesiwala A, Maybaum J, Lawrence T: Role of checkpoint kinase 1 in preventing premature mitosis in response to gemcitabine. Cancer Res 2005, 65:6835-42.

8. Robinson BW, Im MM, Ljungman M, Praz F, Shewach DS: Enhanced radiosensitization with gemcitabine in mismatch repair-deficient HCT116 cells. Cancer Res 2003, 63:6935-6941.

9. Wachters FM, van Putten JWG, Maring JG, Zdzienicka MZ, Groen HJM, Kampinga $\mathrm{HH}$ : Selective targeting of homologous DNA recombination repair by gemcitabine. Int J Rad Oncol Biol Phys 2003, 57:553-562.

10. Pauwels B, Vermorken JB, Wouters A, Ides J, Van LS, Lambrechts HA, Pattyn GG, Vermeulen K, Meijnders P, Lardon F: The role of apoptotic cell death in the radiosensitising effect of gemcitabine. Br J Cancer 2009, 101:628-636.

11. van Putten JWG, Groen HJM, Smid K, Peters GJ, Kampinga HH: End-joining deficiency and radiosensitization induced by gemcitabine. Cancer Res 2001, 61:1585-1591.

12. Jensen A, Debus J, Weber KJ: S-phase cell-specific modification by gemcitabine of PFGE-analyzed radiation-induced DNA fragmentation and rejoining. Int J Radiat Biol 2008, 84:770-777.

13. Flanagan SA, Robinson BW, Krokosky CM, Shewach DS: Mismatched nucleotides as the lesions responsible for radiosensitization with gemcitabine: a new paradigm for antimetabolite radiosensitizers. $\mathrm{Mol}$ Cancer Ther 2007, 6:1858-1868.

14. Van Bree C, Rodermond H, de Vos J, Haveman J, Franken N: Mismatch repair proficiency is not required for radioenhancement by gemcitabine. Int J Radiat Oncol Biol Phys 2005, 62:1504-9.

15. Hanauske AR, Chen V, Paoletti P, Niyikiza C: Pemetrexed disodium: A novel Antifolate clinically active against multiple solid tumors. Oncologist 2001, 6:363-373.

16. Vogelzang NJ, Rusthoven JJ, Symanowski J, Denham C, Kaukel E, Ruffie P, Gatzemeier U, Boyer M, Emri S, Manegold C, Niyikiza C, Paoletti P: Phase III study of pemetrexed in combination with cisplatin versus cisplatin alone in patients with malignant pleural mesothelioma. J Clin Oncol 2003, 21:2636-2644.

17. Hanna N, Shepherd FA, Fossella FV, Pereira JR, De Marinis F, von Pawel J, Gatzemeier U, Tsao TCY, Pless M, Muller T, Lim HL, Desch C, Szondy K, Gervais R, Manegold C, Paul S, Paoletti P, Einhorn L, Bunn PA: Randomized phase III trial of pemetrexed versus docetaxel in patients with nonsmall-cell lung cancer previously treated with chemotherapy. J Clin Oncol 2004, 22:1589-1597. 
18. Scagliotti GV, Parikh P, von PJ, Biesma B, Vansteenkiste J, Manegold C, Serwatowski P, Gatzemeier U, Digumarti R, Zukin M, Lee JS, Mellemgaard A, Park K, Patil S, Rolski J, Goksel T, De MF, Simms L, Sugarman KP, Gandara D: Phase III study comparing cisplatin plus gemcitabine with cisplatin plus pemetrexed in chemotherapy-naive patients with advanced-stage nonsmall-cell lung cancer. J Clin Oncol 2008, 26:3543-3551.

19. Belani CP, Brodowicz T, Ciuleanu T, Kim JH, Krzakowski M, Laack E, Wu YL, Peterson P, Krejcy K, Zielinski C: Maintenance pemetrexed (Pem) plus best supportive care (BSC) versus placebo (Plac) plus BSC: A randomized phase III study in advanced non-small cell lung cancer (NSCLC). J Clin Oncol 2009, 27:CRA8000.

20. Habeck LL, Mendelsohn LG, Shih C, Taylor EC, Colman PD, Gossett LS, Leitner TA, Schultz RM, Andis SL, Moran RG: Substrate specificity of mammalian folylpolyglutamate synthetase for 5,10dideazatetrahydrofolate analogs. Mol Pharmacol 1995, 48:326-333.

21. Shih C, Chen VJ, Gossett LS, Gates SB, MacKellar WC, Habeck LL Shackelford KA, Mendelsohn LG, Soose DJ, Patel VF, Andis SL, Bewley JR, Rayl EA, Moroson BA, Beardsley GP, Kohler W, Ratnam M, Schultz RM: LY231514, a pyrrolo[2,3-d]pyrimidine-based antifolate that inhibits multiple folate-requiring enzymes. Cancer Res 1997, 57:1116-1123.

22. Giovannetti E, Mey V, Nannizzi S, Pasqualetti G, Marini L, Del Tacca M, Danesi R: Cellular and pharmacogenetics foundation of synergistic interaction of pemetrexed and gemcitabine in human non-small-cell lung cancer cells. Mol Pharmacol 2005, 68:110-8.

23. Bischof M, Weber KJ, Blatter J, Wannenmacher M, Latz D: Interaction of pemetrexed disodium (Alimta, multitargeted antifolate) and irradiation in vitro. Int J Rad Oncol Biol Phys 2002, 52:1381-1388.

24. Teicher BA, Alvarez E, Liu PC, Lu K, Menon K, Dempsey J, Schultz RM: MTA (LY231514) in combination treatment regimens using human tumor xenografts and the EMT-6 murine mammary carcinoma. Sem in Oncol 1999, 26:55-62.

25. Teicher BA, Chen V, Shih C, Menon K, Forler PA, Phares VG, Amsrud T: Treatment regimens including the multitargeted antifolate LY231514 in human tumor xenografts. Clin Cancer Res 2000, 6:1016-1023.

26. Seiwert TY, Connell PP, Mauer AM, Hoffman PC, George CM, Szeto L, Salgia R, Posther KE, Nguyen B, Haraf DJ, Vokes EE: A phase I study of pemetrexed, carboplatin, and concurrent radiotherapy in patients with locally advanced or metastatic non-small cell lung or esophageal cancer. Clin Cancer Res 2007, 13:515-522.

27. Specenier PM, Van den Weyngaert D, Van LC, Weyler J, Van den Brande J, Huizing MT, Dyck J, Schrijvers D, Vermorken JB: Phase II feasibility study of concurrent radiotherapy and gemcitabine in chemonaive patients with squamous cell carcinoma of the head and neck: long-term follow up data. Ann Oncol 2007, 18:1856-1860.

28. Pauwels B, Korst AEC, De Pooter CMJ, Pattyn GGO, Lambrechts HAJ Baay MFD, Lardon F, Vermorken JB: Comparison of the sulforhodamine B assay and the clonogenic assay for in vitro chemoradiation studies. Cancer Chemother Pharmacol 2003, 51:221-226.

29. Tonkinson JL, Worzalla JF, Teng CH, Mendelsohn LG: Cell cycle modulation by a multitargeted antifolate, LY231514, increases the cytotoxicity and antitumor activity of gemcitabine in HT29 colon carcinoma. Cancer Res 1999, 59:3671-3676.

30. Giovannetti E, Mey V, Danesi R, Mosca I, Del Tacca M: Synergistic cytotoxicity and pharmacogenetics of gemcitabine and pemetrexed combination in pancreatic cancer cell lines. Clin Cancer Res 2004, 10:2936-2943.

31. Dy GK, Suri A, Reid JM, Sloan JA, Pitot HC, Alberts SR, Goldberg RM, Atherton PJ, Hanson LJ, Burch PA, Rubin J, Erlichman C, Adjei AA: A phase IB study of the pharmacokinetics of gemcitabine and pemetrexed, when administered in rapid sequence to patients with advanced solid tumors. Cancer Chemother Pharmacol 2005, 55:522-30.

32. Treat J, Bonomi P, McCleod M, Christiansen NP, Mintzer DM, Monberg MJ, Ye Z, Chen R, Obasaju CK: Administration of pemetrexed immediately following gemcitabine as front-line therapy in advanced non-small cell lung cancer: a phase II trial. Lung Cancer 2006, 53:77-83.

33. West HL, Wakelee HA, Perry MC, Belt RJ, Chen R, Obasaju C: Gemcitabine and pemetrexed administered in rapid sequence as front-line chemotherapy for advanced non-small-cell lung cancer: a phase II clinical trial. Ann Oncol 2009, 20:850-856.

34. Pauwels B, Korst AEC, Pattyn GGO, Lambrechts HAJ, Van Bockstaele DR, Vermeulen K, Lenjou M, De Pooter CMJ, Vermorken JB, Lardon F: Cell cycle effect of gemcitabine and its role in the radiosensitizing mechanism in vitro. Int J Radiat Oncol Biol Phys 2003, 57:1075-1083.

35. Watson JV, Chambers SH, Smith PJ: A pragmatic approach to the analysis of DNA histograms with a definable G1 peak. Cytometry 1987, 8:1-8.

36. Fertil $B$, Dertinger $H$, Courdi A, Malaise EP: Mean inactivation dose: a useful concept for intercomparison of human cell survival curves. Radiation Res 1984, 99:73-84.

37. Chou TC: Theoretical basis, experimental design, and computerized simulation of synergism and antagonism in drug combination studies. Pharmacol Rev 2006, 58:621-681.

38. Bischof M, Abdollahi A, Gong P, Stoffregen C, Lip KE, Debus JU, Weber KJ, Huber PE: Triple combination of irradiation, chemotherapy (pemetrexed), and VEGFR inhibition (SU5416) in human endothelial and tumor cells. Int J Radiat Oncol Biol Phys 2004, 1220-32.

39. Pauwels B, Korst AEC, De Pooter CMJ, Lambrechts HAJ, Pattyn GGO, Lardon F, Vermorken JB: The radiosensitising effect of gemcitabine and the influence of the rescue agent amifostine in vitro. Eur J Cancer 2003, 39:838-846.

40. Peters GJ, Clavel M, Noordhuis P, Geyssen GJ, Laan AC, Guastalla J, Edzes HT, Vermorken JB: Clinical phase I and pharmacology study of gemcitabine (2', 2'-difluorodeoxycytidine) administered in a two-weekly schedule. J Chemother 2007, 19:212-221.

41. Rinaldi DA, Kuhn JG, Burris HA, Dorr FA, Rodriguez G, Eckhardt SG, Jones S, Woodworth JR, Baker S, Langley C, Mascorro D, Abrahams T, Von Hoff DD: A phase I evaluation of multitargeted antifolate (MTA, LY231514), administered every 21 days, utilizing the modified continual reassessment method for dose escalation. Cancer Chemother Pharmacol 1999, 44:372-380.

42. Nagai S, Takenaka K, Sonobe M, Wada H, Tanaka F: Schedule-dependent synergistic effect of pemetrexed combined with gemcitabine against malignant pleural mesothelioma and non-small cell lung cancer cell lines. Chemotherapy 2008, 54:166-175.

43. Bischof M, Huber P, Stoffregen C, Wannenmacher M, Weber KJ: Radiosensitization by pemetrexed of human colon carcinoma cells in different cell cycle phases. Int J Radiat Oncol Biol Phys 2003, 57:289-292.

44. Tesei A, Ricotti L, De Paola F, Amadori D, Frassineti GL, Zoli W: In vitro schedule-dependent interactions between the multitargeted antifolate LY231514 and gemcitabine in human colon adenocarcinoma cell lines. Clin Cancer Res 2002, 8:233-239.

45. Rodenbach M, Eyol E, Seeli MH, Berger MR: Combination treatment of CC531-lac-Z rat liver metastases by chemoembolization with pemetrexed disodium and gemcitabine. J Cancer Res Clin Oncol 2005, 289-99.

46. Adjei AA, Erlichman C, Sloan JA, Reid JM, Pitot HC, Goldberg RM, Peethambaram P, Atherton P, Hanson LJ, Alberts SR, Jett J: Phase I and pharmacologic study of sequences of gemcitabine and the multitargeted antifolate agent in patients with advanced solid tumors. J Clin Oncol 2000, 18:1748-1757.

47. Ma CX, Nair S, Thomas S, Mandrekar SJ, Nikcevich DA, Rowland KM, Fitch TR, Windschitl HE, Hillman SL, Schild SE, Jett JR, Obasaju C, Adjei AA, North Central Cancer Treatment Group, Mayo C, Eli Lilly \& Company: Randomized phase II trial of three schedules of pemetrexed and gemcitabine as front-line therapy for advanced non-small-cell lung cancer. J Clin Oncol 2005, 23:5929-37.

48. Pauwels B, Korst AE, Pattyn GG, Lambrechts HA, Kamphuis JA, De Pooter CM, Peters GJ, Lardon F, Vermorken JB: The relation between deoxycytidine kinase activity and the radiosensitising effect of gemcitabine in eight different human tumour cell lines. BMC Cancer 2006, 6:142.

49. Gomez H, Santillana S, Vallejos C, Velarde R, Sanchez J, Wang X, Bauer N, Hockett R, Chen V, Niyikiza C, Hanauske A: A Phase II Trial of Pemetrexed in Advanced Breast Cancer: Clinical Response and Association with Molecular Target Expression. Clin Cancer Res 2006, 12:832-8.

50. Giovannetti E, Backus HH, Wouters D, Peters GJ: Functional inactivity and mutations of p53 differentially affect sensitivity to 5-fluorouracil and antifolate inhibitors of thymidylate synthase (TS) by altering TS levels in colorectal cancer cells. Nucleosides Nucleotides Nucleic Acids 2008 , 27:740-745.

51. Tonkinson JL, Marder P, Andis SL, Schultz RM, Gossett LS, Shih C, Mendelsohn LG: Cell cycle effects of antifolate antimetabolites: 
implications for cytotoxicity and cytostasis. Cancer Chemother Pharmacol 1997, 39:521-531.

52. Lu XH, Errington J, Curtin NJ, Lunec J, Newell DR: The impact of p53 status on cellular sensitivity to antifolate drugs. Clin Cancer Res 2001, 7:2114-2123.

53. Giovannetti E, Backus HH, Wouters D, Ferreira CG, van H, Brakenhoff RH, Poupon MF, Azzarello A, Pinedo HM, Peters GJ: Changes in the status of p53 affect drug sensitivity to thymidylate synthase (TS) inhibitors by altering TS levels. Br J Cancer 2007, 96:769-775.

54. Pauwels B, Korst AEC, Andriessen V, Baay MFD, Pattyn GGO, Lambrechts HAJ, De Pooter CMJ, Lardon F, Vermorken JB: Unravelling the mechanism of radiosensitisation by gemcitabine: the role of $\mathrm{p} 53$. Radiation Research 2005, 164:642-50.

55. Chen M, Hough AM, Lawrence TS: The role of p53 in gemcitabinemediated cytotoxicity and radiosensitization. Cancer Chemother Pharmacol 2000, 45:369-374.

Pre-publication history

The pre-publication history for this paper can be accessed here: http://www.biomedcentral.com/1471-2407/10/441/prepub

doi:10.1186/1471-2407-10-441

Cite this article as: Wouters et al:: In vitro study on the scheduledependency of the interaction between pemetrexed, gemcitabine and irradiation in non-small cell lung cancer and head and neck cancer cells. BMC Cancer 2010 10:441.

\section{Submit your next manuscript to BioMed Central} and take full advantage of:

- Convenient online submission

- Thorough peer review

- No space constraints or color figure charges

- Immediate publication on acceptance

- Inclusion in PubMed, CAS, Scopus and Google Scholar

- Research which is freely available for redistribution

Submit your manuscript at www.biomedcentral.com/submit 